University of Nebraska - Lincoln

DigitalCommons@University of Nebraska - Lincoln

Agronomy \& Horticulture - Faculty Publications

Agronomy and Horticulture Department

10-1995

\title{
Adaptability and Reliability of Yield for Four Bell Pepper Cultivars Across Three Southeastern States
}

\author{
Laurie Hodges \\ University of Nebraska-Lincoln, lhodges1@unl.edu \\ Douglas C. Sanders \\ North Carolina State University, doug_sanders@ncsu.edu \\ Katharine B. Perry \\ North Carolina State University, katie_perry@ncsu.edu \\ Kent M. Eskridge \\ University of Nebraska-Lincoln, keskridge1@unl.edu \\ K. M. (Dean) Batal \\ University of Georgia
}

See next page for additional authors

Follow this and additional works at: https://digitalcommons.unl.edu/agronomyfacpub

Part of the Plant Sciences Commons

Hodges, Laurie; Sanders, Douglas C.; Perry, Katharine B.; Eskridge, Kent M.; Batal, K. M. (Dean); Granberry, Darbie M.; McLaurin, Wayne J.; Decoteau, Dennis; Dufault, Robert J.; Garrett, J. Thomas; and Nagata, Russell, "Adaptability and Reliability of Yield for Four Bell Pepper Cultivars Across Three Southeastern States" (1995). Agronomy \& Horticulture -- Faculty Publications. 395.

https://digitalcommons.unl.edu/agronomyfacpub/395

This Article is brought to you for free and open access by the Agronomy and Horticulture Department at DigitalCommons@University of Nebraska - Lincoln. It has been accepted for inclusion in Agronomy \& Horticulture -Faculty Publications by an authorized administrator of DigitalCommons@University of Nebraska - Lincoln. 


\section{Authors}

Laurie Hodges, Douglas C. Sanders, Katharine B. Perry, Kent M. Eskridge, K. M. (Dean) Batal, Darbie M.

Granberry, Wayne J. McLaurin, Dennis Decoteau, Robert J. Dufault, J. Thomas Garrett, and Russell Nagata 


\title{
Adaptability and Reliability of Yield for Four Bell Pepper Cultivars Across Three Southeastern States
}

\author{
Laurie Hodges ${ }^{1}$, Douglas C. Sanders, and Katharine B. Perry \\ Department of Horticultural Science, North Carolina State University, Raleigh, \\ NC 27695-7609
}

Kent M. Eskridge

Department of Biometry, University of Nebraska-Lincoln, Lincoln, NE 68583-0712

K.M. 'Dean' Batal and Darbie M. Granberry
Department of Horticulture, University of Georgia, Tifton, GA 31793

Wayne J. McLaurin

Department of Extension Horticulture, University of Georgia, Athens, GA 30602

\author{
Dennis Decoteau, Robert J. Dufault, J. Thomas Garrett, and \\ Russell Nagata ${ }^{2}$ \\ Department of Horticulture, Clemson University, Clemson, SC 29634
}

Additional index words. alternative crops, Capsicum annuum, reliability index, environmental interaction, Solanaceae

\begin{abstract}
Four bell pepper (Capsicum annuum $\mathbf{L}$.) cultivars were evaluated for yield (total weight of marketable fruit) performance over 41 environments as combinations of 3 years, three planting dates, and seven locations across North Carolina, South Carolina, and Georgia. Cultural practices, including trickle irrigation and double rows planted on blackplastic-covered beds, were uniform across all environments, except for fertilization, which was adjusted at each location based on soil tests. Comparing production over 3 years between the mountain location and the Coastal Plain location in North Carolina, yields were lower on the Coastal Plain. Spring plantings provided higher yields than summer plantings at both locations. Yield increases were obtained from hybrid cultivars over that of the open-pollinated (OP) standard ['Keystone Resistant Giant \#3' (KRG\#3)] in the summer planting in the mountains compared to the Tidewater Coastal Plain. Across the three-state region, hybrid cultivar yields were higher than those of the OP cultivar for the second spring planting date in 1986 and 1987 . Although the hybrid yields were higher than that of the OP standard, the hybrid 'Skipper' yielded less than the other hybrids ('Gator Belle' and 'Hybelle'). 'Gator Belle' generally out-yielded 'Hybelle' at all locations, except in Fletcher, N.C. This difference may be related to the relative sensitivity of these two cultivars to temperature extremes, rather than soil or geographic factors, because there was a tendency for 'Hybelle' yields to exceed 'Gator Belle' in the earliest planting date. Based on the reliability index, the chance of outperforming KRG\#3 (the standard) was $85 \%$ for 'Hybelle', $80 \%$ for 'Gator Belle', but only $67 \%$ for 'Skipper'.
\end{abstract}

Bell pepper is a major crop in the southeastern United States with a total of $\approx 5500$ ha grown in North Carolina, South Carolina, and

\footnotetext{
Received for publication 16 May 1995. Accepted for publication 23 June 1995. Paper no. 12419 of the Journal Series of the North Carolina Agricultural Research Service, Raleigh, and Journal Series no. 10471, Agricultural Research Division, Univ. of Nebraska. The use of trade names in this publication does not imply endorsement by the Agricultural Research Service of North Carolina or Nebraska of the products named, nor criticism of similar ones not mentioned. This study was funded from the U.S. Dept. of Agriculture Special Grant P.L. 89-106. The cost of publishing this paper was defrayed in part by the payment of page charges. Under postal regulations, this paper therefore must be hereby marked advertisement solely to indicate this fact. 'Current address: Dept. of Horticulture, Univ. of NebraskaLincoln, Lincoln, NE 68583-0724.

${ }^{2}$ Current address: Everglades Research \& Education Center, P.O. Box 8003, Belle Glade, FL 33430.
}

Georgia (Vavrina, 1988). Two objectives of a three-state project (Georgia, South Carolina, and North Carolina) are 1) to develop continuous, sequential production, maximizing time in the market from this region and 2) to develop and to disseminate specific recommendations on vegetable crop production (Bauer et al., 1989). Growers express concern that the high cost of hybrid pepper seed may not be returned consistently in higher yields. If specific disease resistance or earliness is not perceived as a market advantage by growers, whatever other benefits the hybrids may convey in disease resistance or earliness may not be as important as consistently high yields. To our knowledge, there is no documentation of the relative performance of commercially available hybrid peppers compared to open- pollinated (OP) inbred cultivars over a range of environments. Evaluating hybrids for yield consistency over a wide range of environments is important to the development of more regional production and marketing systems. Peppers, like other Solanaceae, are recognized as more environmentally sensitive than most other vegetable crops. Temperature, soil moisture, and $\mathrm{N}$ fertility are known to affect pepper yields (Call and Courter, 1989; Cochran, 1936; Quagliotti, 1979, Sanders et al., 1986). The range of environments, soils, and cultural practice used across the southeastern United States preclude uniformity and consistency of pepper production.

Our objectives were to evaluate yield of three hybrid pepper cultivars relative to a standard OP cultivar across diverse environments and to determine the relative reliability of that performance as a measurement of the risk associated with planting hybrid cultivars.

\section{Materials and Methods}

Statistical background. Poysa et al. (1986) reported the difficulties associated with genotype $\times$ environment interactions when developing new cultivars and selecting which cultivars to grow in an area, especially when the variability among either the genotypes or the environments is high. Although using stability analysis techniques based on regression (Eberhart and Russell, 1966; Finlay and Wilkinson, 1964) could help breeders identify genotypes that are stable and high yielding, these methods are limited in their practical application in commercial production because they rely on a fairly sophisticated understanding of statistical methods. It also may be unclear how to weigh the importance of stability to mean performance. Stability analyses also require balanced data sets (i.e., the same cultivars grown in all environments). The relatively few genotypes and many environments used in our study would result in biased regression coefficients with the slopes being highly sensitive to the particular entries evaluated (Crossa, 1990). In our study, we used an alternative method that determines the probability that a cultivar will outperform the standard (Eskridge and Mumm, 1992). This method is understood easily and based on the assumption that the primary concern is to identify cultivars that have a high probability of outperforming a standard or "control" cultivar. This probability is termed the "reliability," and the smaller the reliability, the more risky the cultivar is relative to the standard cultivar. In addition, we use analysis of variance (ANOVA) and contrasts to evaluate the effects of various environmental factors on four pepper cultivars.

Plant material and planting arrangements. Four commercial cultivars were evaluated for performance across 41 diverse environments in the three-state region (North and South Carolina, and Georgia) to characterize how the cultivars interact with environments and to estimate the probabilities of the selected hybrids outperforming an OP control. Seven locations in North Carolina, South Carolina, 
Hodges, Sanders, Perry, Eskridge, Batål, Granberry, McLaurin, Decoteau, Dufault, Garrett \& Nagata in HortScience (1995) 30

\section{Crop Production}

Table 1. Locations and soil type descriptions of pepper planting sites from Spring 1985 to Fall 1987.

\begin{tabular}{|c|c|c|c|c|c|c|}
\hline Location & Geographic region & $\begin{array}{l}\text { Elevation } \\
(\mathrm{m})\end{array}$ & Latitude & Longitude & Soil type & $\begin{array}{r}\text { Mean growing } \\
\text { season (days) }\end{array}$ \\
\hline Mt. Horticultural & & & & & & \\
\hline Research Station, Fletcher, N.C. & South Appalachian Mountains & 621 & N35'26" & W82’34" & $\begin{array}{l}\text { Delanco loam; fine loamy, } \\
\text { mixed mesic Aquic } \\
\text { Hapludult }\end{array}$ & 200 \\
\hline $\begin{array}{l}\text { Peanut Belt Research Station, } \\
\text { Lewiston, N.C. }\end{array}$ & Tidewater Coastal Plain & 15 & N36' $8^{\prime \prime}$ & $\mathrm{W} 77^{\prime} 10^{\prime \prime}$ & $\begin{array}{l}\text { Norfolk sandy loam; fine } \\
\text { sandy, siliceous thermic } \\
\text { Plinthic Paleudult }\end{array}$ & 210 \\
\hline $\begin{array}{l}\text { Coastal Research and Education, } \\
\text { Center Charleston, S.C. }\end{array}$ & Lower eastern Coastal Plain & 3 & $\mathrm{~N} 32^{\circ} 47^{\prime \prime}$ & W79'56" & $\begin{array}{l}\text { Yauhannah fine loamy sand; } \\
\text { siliceous thermic Aquic } \\
\text { Hapludult }\end{array}$ & 290 \\
\hline $\begin{array}{l}\text { Clemson Bottoms Research Station, } \\
\text { Clemson, S.C. }\end{array}$ & Upper Piedmont & 246 & $\mathrm{~N} 34^{\prime} 41^{\prime \prime}$ & W82'49" & $\begin{array}{l}\text { Congaree silt loam; fine } \\
\text { loamy mixed, nonacid, } \\
\text { thermic Typic Udifluvent }\end{array}$ & 205 \\
\hline $\begin{array}{l}\text { Coastal Plain Expt. Station, } \\
\text { Plains, Ga. }\end{array}$ & Central western Coastal Plain & 150 & N32’3" & W84'22"' & $\begin{array}{l}\text { Greenville series; clayey, } \\
\text { kaolinitic, thermic Rhodic } \\
\text { Kandiudult }\end{array}$ & 280 \\
\hline $\begin{array}{l}\text { Coastal Plain Expt. Station, } \\
\text { Tifton, Ga. }\end{array}$ & Lower southwestern Coastal Plain & 108 & N31 $28^{\prime \prime}$ & W83'31" & $\begin{array}{l}\text { Tifton sandy loam; fine } \\
\text { sandy, sliceous thermic } \\
\text { Plinthic Paleudult }\end{array}$ & 296 \\
\hline $\begin{array}{l}\text { Georgia Extension and Research } \\
\text { Station, Attapulgus, Ga. }\end{array}$ & Lower southwestern Coastal Plain & 84 & $\mathrm{~N} 30^{\prime} 42^{\prime \prime}$ & W84'23" & $\begin{array}{l}\text { Norfolk loamy sand; fine } \\
\text { loamy, siliceous thermic } \\
\text { Typic Kandiudult }\end{array}$ & 279 \\
\hline
\end{tabular}

and Georgia (representing diverse soil types and growing seasons, ranging from 200 to 296 days) were selected for field evaluation of bell pepper cultivars (Table 1). Consistent plot size, experiment design, grading standards, and data collection were used in all seven locations for three planting dates in 1985, 1986, and 1987. The first spring planting date was selected for each location based on that location's average spring frost date; the second date was 2 weeks after the first and was considered a planting date with minimal risk. One midsummer or fall planting date was selected to give sufficient time for crop maturity before the average first frost date in the fall. Individual plots were $6 \mathrm{~m}$ long $\times 1.5 \mathrm{~m}$ wide. Two rows of container-grown bell pepper transplants ( 6 to 8 weeks old) were planted on raised beds covered with black polyethylene mulch $(0.04 \mathrm{~mm}$ thick) and trickle irrigated. In-row spacing was $0.3 \mathrm{~m}$ with $0.3 \mathrm{~m}$ between rows on the bed. Bed centers were 1.5 $\mathrm{m}$ apart. A Latin square design of four cultivars was replicated four times at each location. Irrigation, fertilization (based on soil tests), and accepted pest management practices were used in all locations. Peppers were usually harvested weekly at the mature, firm, green stage of development. Total weight of marketable (fancy and U.S. no. 1 and 2) fruit was recorded for each plot, based on U.S. Dept. of Agriculture's standards (1989).

Four commercial cultivars were selected using the following criteria: 1) OP and hybrid cultivars and 2) at least one cultivar known to perform well under commercial cultivation in each of the three states. 'Keystone Resistant Giant \#3' (KRG\#3), an OP cultivar, is planted widely in the southeastern United States. The hybrid 'Gator Belle' performed well in commercial production in Georgia but was not
Table 2. Analysis of variance and specific contrasts for total marketable yields of four pepper cultivars in Fletcher (F) and Lewiston (L), N.C., for three planting dates (PD) from 1985 to 1987.

\begin{tabular}{|c|c|c|c|}
\hline Variable & $\mathrm{df}$ & $\mathrm{MS}^{2}$ & $P<\mathrm{F}$ \\
\hline Location & 1 & 570 & 0.0034 \\
\hline Year & 2 & 278 & 0.0148 \\
\hline PD & 2 & 11779 & 0.0001 \\
\hline Spring vs. summer & 1 & 23552 & 0.0001 \\
\hline PD1 vs. PD2 & 1 & 6 & 0.7536 \\
\hline Location $\times$ year & 2 & 5775 & 0.0001 \\
\hline Location $\times$ PD & 2 & 2340 & 0.0001 \\
\hline Spring vs. summery, L vs. F & 1 & 3678 & 0.0001 \\
\hline PD1 vs. PD2, L vs. F & 1 & 1002 & 0.0001 \\
\hline Year $\times$ PD & 4 & 2340 & 0.0001 \\
\hline Location $\times$ year $\times$ PD & 4 & 8976 & 0.0001 \\
\hline Row (location × year × PD) & 54 & 150 & 0.0001 \\
\hline Column (location $\times$ year $\times$ PD) & 54 & 113 & 0.0053 \\
\hline $\begin{array}{l}\text { Cultivar } \\
\text { late }\end{array}$ & 3 & 1385 & 0.0001 \\
\hline Open (OP) vs. hybrid ${ }^{x}$ & 1 & 1834 & 0.0001 \\
\hline \multicolumn{4}{|l|}{ Skipper (SK) vs. Gator Belle $(\mathrm{G})+$} \\
\hline Hybelle $(\mathrm{H})$ & 1 & 1322 & 0.0001 \\
\hline G vs. H & 1 & 945 & 0.0002 \\
\hline Location $\times$ cultivar & 3 & 322 & 0.0025 \\
\hline OP vs. hybrid, L vs. F & 1 & 121 & 0.1699 \\
\hline SK vs. $\mathrm{G}+\mathrm{H}, \mathrm{L}$ vs. $\mathrm{F}$ & 1 & 8 & 0.7223 \\
\hline G vs. H, L vs. F & 1 & 836 & 0.0004 \\
\hline Year $\times$ cultivar & 6 & 659 & 0.0001 \\
\hline PD $\times$ cultivar & 6 & 195 & 0.0081 \\
\hline OP vs. hybrid, spring vs. summer & 1 & 75 & 0.2795 \\
\hline SK vs. $\mathrm{G}+\mathrm{H}$, spring vs. summer & 1 & 852 & 0.0004 \\
\hline G vs. H, spring vs. hummer & 1 & 29 & 0.5109 \\
\hline OP vs. hybrid, PD1 vs. PD2 & 1 & 48 & 0.3885 \\
\hline SK vs. G+H, PD1 vs. PD2 & 1 & 154 & 0.1220 \\
\hline G vs. H, PD1 vs. PD 3 & 1 & 37 & 0.4499 \\
\hline Location $\times$ year $\times$ cultivar & 6 & 253 & 0.0012 \\
\hline Location $\times \mathrm{PD} \times$ cultivar & 6 & 66 & 0.4004 \\
\hline OP vs. hybrid, spring vs. summer, F vs. L & 1 & 193 & 0.0842 \\
\hline OP vs. hybrid, PD1 vs. PD2. F vs. L & 1 & 55 & 0.3521 \\
\hline SK vs. $\mathrm{G}+\mathrm{H}$, spring vs. summer, F vs. $\mathrm{L}$ & 1 & 17 & 0.6009 \\
\hline SK vs. G + H, PD1 vs. PD2, F vs. L & 1 & 15 & 0.6235 \\
\hline G vs. $H$, spring vs. summer, F vs. $L$ & 1 & 42 & 0.4191 \\
\hline Year $\times \mathrm{PD} \times$ cultivar & 12 & 79 & 0.2607 \\
\hline Location $\times$ year $\times \mathrm{PD} \times$ cultivar & 12 & 70 & 0.3586 \\
\hline Error & 108 & 63 & \\
\hline
\end{tabular}

${ }^{\mathrm{M}} \mathrm{MS}=$ mean squares (rounded to whole numbers).

${ }^{y}$ Spring $=$ average of PD1 and PD2; summer $=$ PD 3.

${ }^{\circ} \mathrm{OP}=$ open-pollinated 'Keystone Resistant Giant \#3'; hybrid = the average of the three hybrid cultivars Gator Belle, Hybelle, and Skipper. 
grown commercially in the other two states. The hybrid 'Skipper' was grown in North and South Carolina, and the hybrid 'Hybelle' performed well in limited trials in the mountain region of North Carolina, but it was not grown widely elsewhere in the region.

Results were not available for all locations, years, or planting dates. Preliminary analysis of variance indicated that cultivar performance differed with year, location, and planting date. Each specific combination of year, planting date, and location was designated an environment, and the cultivar $\times$ environment interaction was found to be significant at $P<0.0001$ using the appropriate ANOVA. To aid understanding the cultivar $\times$ environment interaction, two balanced data sets were selected. One set consisted of pepper yields from the two North Carolina locations (Fletcher in the southern Appalachian Mountain region and Lewiston on the Tidewater Coastal Plain) in 3 years (1985 to 1987) and three planting dates (two spring and one summer). Interactions were tested using ANOVA. When interactions were significant, specific contrasts were used to understand how the cultivars interacted with planting dates, locations, and years. The second balanced data set consisted of the second spring planting date in 1986 and 1987 across six of the seven geographical locations. Tifton, Ga., was not represented in this data set because the research was moved to Plains, Ga., in 1986. Again, interactions were tested with ANOVA, and specific contrasts were made to evaluate how the cultivars interacted with selected locations based on particular geographical or soil characteristics. These data provide information on the performance of specific cultivars across regions.

Beyond identifying the highest yielding cultivars within the region, the riskiness of changing a cultivar selection should be considered by growers. Hybrid pepper cultivar seed cost much more than OP seed (about $\$ 221$ vs. $\$ 27 / \mathrm{kg}$ ). Consequently, it is important that a hybrid have a high probability of outperforming standard OP cultivars (such as KRG\#3) before the hybrid can be promoted for sequential production throughout a broad geographical region. Therefore, we estimated and tested the reliability of each of the hybrid cultivars having a yield higher than the OP standard cultivar across all environments using the methods described by Eskridge and Mumm (1992).

\section{Results}

Cultivar performance in North Carolina. Within North Carolina, yields of the four cultivars were compared using the two diverse locations of Fletcher, in the southern Appalachian Mountains, and Lewiston, on the Tidewater Coastal Plain. There was a significant three-way interaction of location, year, and cultivar $(P=0.0012)$. A major factor contributing to this interaction was that in Lewiston, the hybrid 'Gator Belle' performed best among the cultivars in 1985 and 1987 but the poorest in 1986; 'Hybelle' performed best among the four at Fletcher in 1985 and 1986 (Table 2).
The location $\times$ planting date $\times$ cultivar interaction was not significant $(P=0.4004)$. Specific contrasts were made to interpret the response of the cultivars across the planting dates and geographic locations in North Carolina. There was significantly greater difference between the marketable yield of the OP KRG\#3 and that of the hybrids from the summer planting at Fletcher (30\% lower yield) when compared to the summer planting at Lewiston $(14 \%$ lower yield) (Table 3). This large difference in performance between the OP peppers and the hybrids in the summer planting was not found for the spring plantings, where the average yield of the OP cultivar from the two spring plantings was only $9 \%$ to $10 \%$ lower than the average hybrid yield in Fletcher and Lewiston (Table 3).

Yield response to planting date depended on the location, as shown by a significant planting date $\times$ location interaction. At Fletcher, the highest yields occurred at the earliest planting date; however, there was a slight improvement in yield at Lewiston by delaying planting to the second spring planting date or $\approx 2$ weeks after the average latest spring frost date (Table 3 ). At both locations, spring plantings provided consistently higher yields than the summer planting.

The relative performance of cultivars depended on planting date, as indicated by a significant cultivar $\times$ planting date interaction $(P=0.0081)$. Contrasts indicated that 'Skipper' yielded less than the average of the other two hybrids from the spring plantings (44.99 vs. $\left.53.46 \mathrm{Mg} \cdot \mathrm{ha}^{-1}\right)$ but had about the same yield in the summer planting (32.16 vs. 31.91 $\left.\mathrm{Mg} \cdot \mathrm{ha}^{-1}\right)$. The yield difference among the other cultivars was consistent across planting dates.

Table 3. Three-year average yield $\left(\mathrm{Mg} \cdot \mathrm{ha}^{-1}\right)$ comparison for three planting dates (PD) of the open-pollinated pepper cultivar KRG\#3 with three hybrid pepper cultivars grown in the mountains (Fletcher) or Coastal Plain (Lewiston) of North Carolina.

\begin{tabular}{|c|c|c|c|c|c|c|}
\hline \multirow[b]{2}{*}{ Location } & \multirow[b]{2}{*}{ Cultivar } & \multicolumn{3}{|c|}{ PD } & \multirow{2}{*}{$\begin{array}{c}\text { Avg } \\
\text { PD } 1+\text { PD } 2\end{array}$} & \multirow{2}{*}{$\begin{array}{l}\text { Avg } \\
3 \text { PDs }\end{array}$} \\
\hline & & 1 & 2 & 3 & & \\
\hline \multirow{7}{*}{ Fletcher } & KRG\#3 & 44.70 & 44.85 & 27.79 & 44.77 & 39.11 \\
\hline & Gator Belle & 47.14 & 45.71 & 36.00 & 46.46 & 42.95 \\
\hline & Hybelle & 61.46 & 54.08 & 46.15 & 57.77 & 52.90 \\
\hline & Skipper & 48.37 & 40.21 & 39.91 & 44.29 & 42.83 \\
\hline & All hybrids & 52.32 & 46.67 & 39.69 & 49.50 & 46.23 \\
\hline & $\begin{array}{l}\text { Gator Belle + } \\
\text { Hybelle }\end{array}$ & 54.30 & 49.89 & 39.58 & 52.10 & 47.92 \\
\hline & Cultivar average & 50.42 & 46.21 & 36.71 & 48.31 & 44.45 \\
\hline \multirow[t]{7}{*}{ Lewiston } & KRG\#3 & 44.49 & 49.28 & 21.27 & 46.89 & 38.35 \\
\hline & Gator Belle & 51.53 & 57.93 & 23.96 & 54.73 & 44.48 \\
\hline & Hybelle & 51.20 & 58.62 & 24.52 & 54.91 & 44.78 \\
\hline & Skipper & 45.14 & 46.25 & 25.41 & 45.70 & 38.94 \\
\hline & All hybrids & 49.29 & 54.27 & 24.63 & 51.78 & 42.73 \\
\hline & $\begin{array}{l}\text { Gator Belle + } \\
\text { Hybelle }\end{array}$ & 51.37 & 58.28 & 24.24 & 54.82 & 44.63 \\
\hline & Cultivar average & 48.09 & 53.02 & 23.79 & 50.56 & 41.63 \\
\hline \multirow[t]{7}{*}{$\begin{array}{l}\text { Average of } \\
\text { both locations }\end{array}$} & KRG\#3 & 44.59 & 47.06 & 24.53 & 45.83 & 38.73 \\
\hline & Gator Belle & 49.34 & 51.82 & 29.98 & 50.58 & 43.71 \\
\hline & Hybelle & 56.33 & 56.35 & 33.84 & 56.34 & 48.84 \\
\hline & Skipper & 46.76 & 43.23 & 32.66 & 44.99 & 40.88 \\
\hline & All hybrids & 50.81 & 50.47 & 32.16 & 50.64 & 44.48 \\
\hline & $\begin{array}{l}\text { Gator Belle + } \\
\text { Hybelle }\end{array}$ & 52.83 & 54.09 & 31.91 & 53.46 & 46.28 \\
\hline & Cultivar average & 49.25 & 46.62 & 30.25 & 49.44 & 43.04 \\
\hline
\end{tabular}

Dates 1 and 2 = spring, 3 = summer; root mean square error $=7.97$; KRG\#3 = 'Keystone Resistant Gian \#3', an open-pollinated cultivar; hybrid = the average of the three hybrid cultivars Gator Belle, Hybelle, and Skipper. depended on location as indicated by a significant cultivar $\times$ location interaction $(P=0.0025)$.

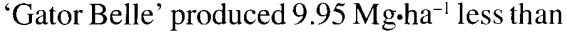
'Hybelle' in Fletcher, but this difference did not occur at Lewiston. There were no other significant differences in cultivar performance

Cultivar performance across three southeastern states. A balanced data set consisting of the second spring planting date in 1986 and 1987 at all locations except Tifton, Ga., was used to better understand the performance of the selected cultivars across the geographic area. The location $\times$ cultivar $\times$ year interaction was significant $(P=0.0208)$, indicating that the cultivars responded differently to geographical location and year (Table 4). Using contrasts between the single mountain location of Fletcher and all other locations $(P=$ 0.0011 ), the average marketable yield of 'Gator Belle' in Fletcher was $\approx 30 \%$ less than the average of 'Hybelle' at this planting date in 1986, compared to an average of only $5 \%$ less than the average across all other locations (Tables 5-7). In 1987, 'Gator Belle' produced $\approx 50 \%$ more marketable yield than 'Hybelle' in Fletcher but averaged $\approx 18 \%$ more than 'Hybelle' across all other locations (Table 8). These differences were significant in 1986 but not in 1987 (ANOVA not shown).

The relative performance of the cultivars in sandy vs. silty soils also was compared using contrasts (Tables 5-7). Locations grouped as sandy soils were Attapulgus, Ga.; Charleston, S.C; and Lewiston. Silty soils were found at Clemson, S.C., and Plains. Again, 'Gator Belle' and 'Hybelle' performed differently under these conditions in 1986 and 1987
The cultivars' relative performance also between the two locations in North Carolina. 
$(P=0.0021)$. In 1986, 'GatorBelle' yielded $\approx 23 \%$ less than 'Hybelle' on the sandy soils but $\approx 59 \%$ more on the silty soils, a significant difference $(P=0.0007)$. However, in 1987 , when 'GatorBelle' yielded $\approx 19 \%$ more than 'Hybelle' on sandy soils and $\approx 11 \%$ more on silty soils, these differences were not significant $(P>0.05)$. Although cultivar performance differed across years $(P=0.0010)$, the only significant contrast was between 'GatorBelle' and 'Hybelle'. The yield difference between these two hybrids was significant within each year. In 1986, 'GatorBelle' produced $15 \%$ less than 'Hybelle'; in 1987, it produced $22 \%$ more than 'Hybelle' across all locations. There was no significant difference in cultivar performance across all locations (location $\times$ cultivar, $P=0.2695$ ). The average yield of KRG\#3 across all locations at the second planting date in 1986 and 1987 was $11 \%$ less than that of the hybrids $(P=0.0027)$ and 'Skipper' produced significantly less than the combined average of the other two hybrids (27.23 vs. $32.97 \mathrm{Mg} \cdot \mathrm{ha}^{-1}$ ). Yields were significantly higher in Fletcher compared with all other locations in 1986 (68.62 vs. $21.28 \mathrm{Mg} \cdot \mathrm{ha}^{-}$ 1) but not in 1987 (28.54 vs. $\left.31.76 \mathrm{Mg} \cdot \mathrm{ha}^{-1}\right)$. In the most southern location, Attapulgus, the average yield in 1986 was similar to those in all other locations; in 1987, yields in Attapulgus were significantly higher than at all other locations (44.30 vs. $28.59 \mathrm{Mg} \cdot \mathrm{ha}^{-1}$ ). Yields were significantly higher on sandy soils in 1986 and 1987 , with a 1.5 times greater overall yield in 1986 and a 4.2 times greater yield in 1987. Average yields in Clemson in the Piedmont at the second planting date over the two years were only $20 \%$ of those on the Coastal Plain (6.14 vs. $29.98 \mathrm{Mg} \cdot \mathrm{ha}^{-1}$ ). In 1986, the low yields in Clemson are attributed to failure of the irrigation system when peppers in planting date 1 were sizing and those in planting date 2 were setting fruit.

Reliability of yield of hybrids vs. the $O P$ cultivar. The reliability index (RI) (Table 9) is the estimated probability of outperforming the standard cultivar and measures the risk involved in the change from a standard cultivar to another (Eskridge and Mumm, 1992). The RI was estimated using marketable fruit weights from all locations and planting dates from 1985 to 1987. The OP KRG\#3 was selected as the standard cultivar because it has been recommended and frequently planted throughout the region. The RI indicated 'Hybelle' had an $85 \%$ chance of having a marketable yield higher than KRG\#3, 'Gator Belle' had an $80 \%$ chance, and 'Skipper' had a $67 \%$ chance. 'Hybelle' was significantly more reliable $(P<0.05)$ than 'Skipper' but not 'Gator Belle'.

\section{Discussion}

Location. Bell pepper cultivars varied in adaptation to the various environments evaluated in this study. The difference in adaptation is particularly marked for 'Gator Belle', which dropped to the second rank in Fletcher and Lewiston when averaged across all planting dates and years. In all locations south of North
Carolina, 'Gator Belle' ranked as the top cultivar in total marketable yield, although this difference was not statistically significant. In North Carolina, 'Hybelle' was the highestyielding cultivar. Across all locations and years, 'Hybelle' tended to yield only slightly (nonsignificantly) more than 'GatorBelle' at the first planting date. 'Hybelle' produced the lowest yield of the hybrids in the third planting date, although this difference was nonsignificant. These tendencies may reflect adaptation for cooler conditions, although this interpretation needs to be verified. Across all cultivars, years, and planting dates, the total weight of fruit harvested was highest in Fletcher, which might be attributable to the cooler nights.

Temperatures. Flower development and fruit set of pepper is inhibited mainly by night temperatures $>30 \mathrm{C}$ (Dorland and Went, 1947), with the optimum range for flower develop- ment being 16 to 20C (Quagliotti, 1979). Deal and Raulston (1989) reported the average night temperature in Lewiston exceeds this optimum range by 2 to $4 \mathrm{C}$ during June, July, and August, but average night temperatures remain between 16 and $18 \mathrm{C}$ in Fletcher during these same months, rarely exceeding $20 \mathrm{C}$. High summer night temperatures of the more southern locations may limit flower development and fruit set.

'Gator Belle' appeared to be more sensitive to temperature than the other cultivars as expressed through the significant cultivar $x$ location $\times$ year interaction in North Carolina $(P=0.0012)$, which is particularly noticeable in the 1986 data. A review of temperature records reveals that the average night temperature in Lewiston was $15 \mathrm{C}$ the night following transplanting in 1986; it increased to $21 \mathrm{C}$ two days later before dropping to an average of 7 to

Table 4. Analysis of variance for planting date (PD) 2 (second spring planting date) in 1986 and 1987 across six geographical locations in three southeastern states.

\begin{tabular}{|c|c|c|c|}
\hline Variable $^{z}$ & $\mathrm{df}$ & $\mathrm{MS}^{\mathrm{y}}$ & $\mathrm{P}<\mathrm{F}$ \\
\hline Location & 5 & 10,766 & 0.0001 \\
\hline Mountain (Mt.) vs. other & 1 & 12,921 & 0.0001 \\
\hline Coastal Plain (CP) vs. Piedmont & 1 & 16,618 & 0.0001 \\
\hline Sandy vs. dilty & 1 & 18,338 & 0.0001 \\
\hline Attapulgus vs. other & 1 & 1,549 & 0.0001 \\
\hline Year $(Y)$ & 1 & 199 & 0.0697 \\
\hline Location $\times \mathrm{Y}$ & 5 & 7711 & 0.0001 \\
\hline Mt. vs. other & 1 & 17,104 & 0.0001 \\
\hline CP vs. Piedmont & 1 & 0.02 & 0.9836 \\
\hline Sandy vs. silty & 1 & 6,424 & 0.0001 \\
\hline Attapulgus vs. other & 1 & 1,746 & 0.0001 \\
\hline Row (location $\times \mathrm{Y}$ ) & 36 & 177 & 0.0001 \\
\hline Column (location $\times \mathrm{Y}$ ) & 36 & 106 & 0.0167 \\
\hline Cultivar & 3 & 504 & 0.0001 \\
\hline OP vs. other & 1 & 565 & 0.0027 \\
\hline Skipper vs. $\mathrm{G}+\mathrm{H}$ & 1 & 885 & 0.0002 \\
\hline G vs. $\mathrm{H}$ & 1 & 26 & 0.5102 \\
\hline Location $\times$ cultivar & 15 & 72 & 0.2695 \\
\hline OP vs. other, Mt. vs. other & 1 & 19 & 0.5696 \\
\hline Skipper vs. $\mathrm{G}+\mathrm{H}$, Mt. vs. other & 1 & 119 & 0.1587 \\
\hline G vs. H, Mt. vs. other & 1 & 211 & 0.0618 \\
\hline OP vs. other, CP vs. Piedmont & 1 & 0.22 & 0.9510 \\
\hline Skipper vs. $\mathrm{G}+\mathrm{H}, \mathrm{CP}$ vs. Piedmont & 1 & 4 & 0.7847 \\
\hline G vs. $\mathrm{H}, \mathrm{CP}$ vs. Piedmont & 1 & 18 & 0.5803 \\
\hline OP vs. other, sandy vs. silty & 1 & 17 & 0.5951 \\
\hline Skipper vs. $\mathrm{G}+\mathrm{H}$, sandy vs. silty & 1 & 0.18 & 0.9565 \\
\hline G vs. $H$, sandy vs. silty & 1 & 80 & 0.2464 \\
\hline OP vs. other, Attapulgus vs. other & 1 & 71 & 0.2742 \\
\hline Skipper vs. $\mathrm{G}+\mathrm{H}$, Attapulgus vs. other & 1 & 31 & 0.4668 \\
\hline G vs. H, Attapulgus vs. other & 1 & 8 & 0.7111 \\
\hline $\mathrm{Y} \times$ cultivar & 3 & 355 & 0.0010 \\
\hline OP vs. other & 1 & 93 & 0.2126 \\
\hline Skipper vs. $\mathrm{G}+\mathrm{H}$ & 1 & 136 & 0.1321 \\
\hline G vs. H & 1 & 831 & 0.0003 \\
\hline Location $\times \mathrm{Y} \times$ cultivar & 15 & 122 & 0.0208 \\
\hline OP vs. other, Mt. vs. other & 1 & 2 & 0.8622 \\
\hline Skipper vs. G + H, Mt. vs. other & 1 & 0.25 & 0.9476 \\
\hline G vs. H, Mt. vs. other & 1 & 679 & 0.0011 \\
\hline OP vs. other, CP vs. Piedmont & 1 & 48 & 0.3669 \\
\hline Skipper vs. $\mathrm{G}+\mathrm{H}$, CP vs. Piedmont & 1 & 37 & 0.4290 \\
\hline $\mathrm{G}$ vs. $\mathrm{H}, \mathrm{CP}$ vs. Piedmont & 1 & 114 & 0.1679 \\
\hline OP vs. other, sandy vs. silty & 1 & 4 & 0.7964 \\
\hline Skipper vs. $\mathrm{G}+\mathrm{H}$, sandy vs. silty & 1 & 56 & 0.3325 \\
\hline G vs. $H$, sandy vs. silty & 1 & 598 & 0.0021 \\
\hline OP vs. other, Attapulgus vs. other & 1 & 137 & 0.1316 \\
\hline Skipper vs. $\mathrm{G}+\mathrm{H}$, Attapulgus vs. other & 1 & 108 & 0.1793 \\
\hline G vs. H, Attapulgus vs. other & 1 & 42 & 0.4016 \\
\hline Error & 72 & 59 & \\
\hline
\end{tabular}

${ }^{2} \mathrm{OP}=$ open-pollinated cultivar KRG\#3; hybrid = the average of the three hybrid cultivars Gator Belle, Hybelle, and Skipper; $\mathrm{G}=$ Gator Belle; $\mathrm{H}=$ Hybelle; $\mathrm{S}=$ Skipper.

${ }^{y}$ Mean squares have been rounded to whole numbers. 


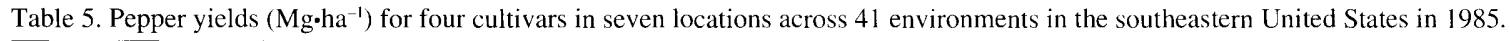

\begin{tabular}{|c|c|c|c|c|c|c|c|c|c|c|}
\hline \multirow[b]{3}{*}{ Cultivar } & \multicolumn{10}{|c|}{ Location $^{2}$} \\
\hline & \multirow{2}{*}{$\frac{\text { Attapulgus, Ga. }}{15 \mathrm{Aug} .}$} & \multirow{2}{*}{$\frac{\text { Charleston, S.C. }}{31 \text { July }}$} & \multirow{2}{*}{$\frac{\text { Clemson, S.C. }}{1 \text { Aug. }}$} & \multicolumn{3}{|c|}{ Fletcher, N.C. } & \multicolumn{3}{|c|}{ Lewiston, N.C. } & \multirow{2}{*}{$\frac{\text { Tifton, Ga }}{7 \text { Aug. }}$} \\
\hline & & & & 16 May & 3 June & 18 June & $30 \mathrm{Apr}$. & 16 May & 18 July & \\
\hline Gator Belle & 12.35 & 12.87 & 9.7 & 31.05 & 43.91 & 43.84 & 63.77 & 62.86 & 17.31 & 8.66 \\
\hline Hybelle & 11.83 & 14.01 & 10.30 & 57.78 & 57.80 & 54.67 & 57.19 & 61.08 & 14.50 & 7.13 \\
\hline KRG\#3 & 7.18 & 8.72 & 9.85 & 24.67 & 38.75 & 33.69 & 49.00 & 47.02 & 15.13 & 4.10 \\
\hline Skipper & 11.43 & 10.93 & 10.92 & 27.73 & 25.79 & 44.40 & 54.03 & 50.07 & 12.13 & 7.83 \\
\hline
\end{tabular}

가anting dates 1 and 2 were missed in Attapulgus, Charleston, Clemson, and Tifton.

Table 6. Pepper yields (Mg.ha-1) for four cultivars in seven locations across 41 environments in the southeastern United States in 1986.

\begin{tabular}{|c|c|c|c|c|c|c|c|c|c|c|c|c|c|c|c|c|}
\hline \multirow[b]{3}{*}{ Cultivar } & \multicolumn{16}{|c|}{ Location } \\
\hline & \multicolumn{3}{|c|}{ Attapulgus, Ga. } & \multicolumn{2}{|c|}{ Charleston, S.C. ${ }^{\text {? }}$} & \multicolumn{2}{|c|}{ Clemson, S.C. ${ }^{y}$} & \multicolumn{3}{|c|}{ Fletcher, N.C. } & \multicolumn{3}{|c|}{ Lewiston, N.C. } & \multicolumn{3}{|c|}{ Plains, Ga. } \\
\hline & 17 Mar. & 31 Mar. & 18 Aug. & 1 Apr. & 6 Aug. & $18 \mathrm{Apr}$. & 1 May & 23 May & 4 June & 16 June & 5 May & 20 May & 14 July & 24 Mar. & 9 Apr. & $12 \mathrm{Aug}$ \\
\hline Gator Belle & 34.15 & 26.23 & 38.59 & 20.39 & 20.90 & 9.30 & 2.09 & 49.44 & 56.77 & 26.82 & 27.46 & 24.21 & 35.67 & 52.86 & 40.84 & 17.88 \\
\hline KRG\#3 & 33.36 & 27.93 & 27.46 & 17.22 & 21.50 & 4.52 & 0.99 & 62.16 & 67.71 & 24.83 & 32.74 & 24.18 & 37.51 & 26.11 & 26.21 & 13.14 \\
\hline Skipper & 35.88 & 25.62 & 40.54 & 17.30 & 21.83 & 4.62 & 0.26 & 58.47 & 69.85 & 35.06 & 31.30 & 22.57 & 49.49 & 39.03 & 30.13 & 12.07 \\
\hline
\end{tabular}

2 Planting date 1 was missed.

yPlanting date 3 was missed.

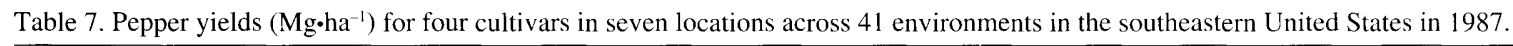

\begin{tabular}{|c|c|c|c|c|c|c|c|c|c|c|c|c|c|c|c|}
\hline \multirow[b]{3}{*}{ Cultivar } & \multicolumn{15}{|c|}{ Location } \\
\hline & \multicolumn{3}{|c|}{ Attapulgus, Ga. } & \multicolumn{2}{|c|}{ Charleston, S.C. ${ }^{z}$} & \multicolumn{2}{|c|}{ Clemson, S.C. ${ }^{z}$} & \multicolumn{3}{|c|}{ Fletcher, N.C. } & \multicolumn{3}{|c|}{ Lewiston, N.C. } & \multicolumn{2}{|c|}{ Plains, Ga. ${ }^{y}$} \\
\hline & 17 Mar. & 23 Mar. & 16 July & 23 Mar. & $7 \mathrm{Apr}$. & 23 Apr. & 8 May & 21 May & 1 June & 15 June & 4 May & 18 May & 23 July & $17 \mathrm{Apr}$. & $13 \mathrm{Aug}$. \\
\hline Gator Belle & 44.17 & 52.27 & 8.92 & 22.90 & 22.08 & 29.25 & 16.33 & 60.94 & 36.45 & 37.34 & 63.42 & 86.73 & 18.90 & 17.42 & 20.68 \\
\hline Hybelle & 41.43 & 43.70 & 12.75 & 17.14 & 14.11 & 28.48 & 17.14 & 57.23 & 24.28 & 33.64 & 54.67 & 77.18 & 22.54 & 13.36 & 18.63 \\
\hline KRG\#3 & 31.88 & 37.16 & 6.28 & 16.56 & 14.51 & 10.60 & 4.99 & 47.26 & 28.07 & 24.84 & 51.74 & 76.65 & 11.17 & 5.57 & 8.93 \\
\hline Skipper & 38.69 & 44.07 & 7.92 & 16.19 & 13.53 & 15.15 & 6.96 & 58.91 & 24.99 & 40.24 & 50.10 & 66.11 & 14.62 & 5.34 & 18.74 \\
\hline
\end{tabular}

${ }^{2}$ Planting date 3 was missed.

yPlanting date 1 was missed.

$8 \mathrm{C}$ for the next two nights, before returning to about $12 \mathrm{C}$. In Fletcher, the average night temperature was $8 \mathrm{C}$; it rose to $\approx 15 \mathrm{C}$ during the week after planting and then remained near $15 \mathrm{C}$ through the rest of the season. Although the 1986 planting in Fletcher was subjected to low temperatures the night after planting for the first planting date, these plants were subjected only to the lower temperatures for one night and had not been exposed to the higher temperatures experienced in Lewiston during the week after transplanting and before the temperature drop. Differences between cultivars in susceptibility to temperature stress, either due to low or fluctuating temperatures, may account for the much lower yield of 'Gator Belle' in 1986 in Lewiston than in 1985 or 1987. Over the three years of this study, there was a general warming trend, with average day and average night temperatures increasing. Because 'Hybelle' exceeded 'Gator Belle' in yield only in Fletcher and Lewiston, it appears that 'Hybelle' may be less sensitive to temperature extremes and better adapted to situations where low temperatures occur during the production season. Detailed temperature data for other locations were not available.

Soil type. Specific contrasts show significant differences in pepper yields between Fletcher and all other locations, sandy soil compared with silty soils, and between Attapulgus and all other locations. The higher yields in sandy soils than in silty soils may be related to a better environment for root growth on the lighter soils. The magnitude of these differences may have been compounded by the low yields in Clemson (silty soil) in 1986

Table 8. Comparison of pepper cultivar yields at the second planting date in 1986 and 1987 for six locations throughout the southeastern United States.

\begin{tabular}{|c|c|c|c|c|c|c|}
\hline \multirow{4}{*}{$\begin{array}{l}\text { Year and } \\
\text { cultivar } \\
1086\end{array}$} & \multicolumn{6}{|c|}{ Marketable yield $\left(\mathrm{Mg} \cdot \mathrm{ha}^{-1}\right)$} \\
\hline & \multirow{2}{*}{\multicolumn{2}{|c|}{ Fletcher, N.C., vs. all others ${ }^{x}$}} & \multicolumn{2}{|c|}{ Soils } & \multirow{2}{*}{\multicolumn{2}{|c|}{ Attapulgus, Ga., vs. all other }} \\
\hline & & & \multirow{2}{*}{ Sandy } & \multirow[t]{2}{*}{ Silty } & & \\
\hline & & & & & & \\
\hline Gator Belle & 55.77 & 22.75 & 23.61 & 21.47 & 26.23 & 28.86 \\
\hline Hybelle & 80.15 & 23.90 & 30.85 & 13.47 & 35.33 & 32.89 \\
\hline Skipper & 69.85 & 19.18 & 21.83 & 15.20 & 25.62 & 28.02 \\
\hline KRG\#3 & 67.71 & 19.31 & 23.11 & 13.60 & 27.93 & 27.26 \\
\hline Average & 68.62 & 21.28 & 24.85 & 15.93 & 28.78 & 29.25 \\
\hline 1987 & & & & & & \\
\hline Gator Belle & 36.46 & 38.91 & 53.70 & 16.88 & 52.27 & 35.80 \\
\hline Hybelle & 24.28 & 33.10 & 45.00 & 15.25 & 43.70 & 29.21 \\
\hline Skipper & 24.99 & 27.20 & 41.24 & 6.15 & 44.07 & 23.39 \\
\hline KRG\#3 & 28.07 & 27.78 & 42.78 & 5.28 & 37.16 & 25.96 \\
\hline Average & 28.04 & 31.76 & 45.68 & 10.89 & 44.30 & 28.59 \\
\hline
\end{tabular}

${ }^{`}$ Sandy soil = Lewiston and Charleston; silty soil = Clemson, Plains, and Attapulgus.

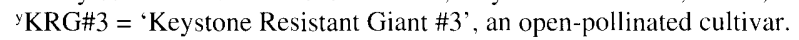

${ }^{x}$ All others than Fletcher includes Clemson, Lewiston, Charleston, Plains, and Attapulgus. All others than Attapulgus includes all of these plus Fletcher. Root mean square error $=7.66$.

Table 9. Reliability of yield for four bell pepper cultivars grown in 41 environments (years $\times$ planting dates $\times$ locations) across North Carolina, South Carolina, and Georgia where 'Keystone Resistant Giant \#3' (KRG\#3) is the standard cultivar.

\begin{tabular}{|c|c|c|c|c|}
\hline Cultivar & $\begin{array}{c}\text { Yield } \\
\left({\left.\mathrm{Mg} \cdot h \mathrm{a}^{-1}\right)}\right.\end{array}$ & $\begin{array}{c}\text { Mean } \\
\text { difference }\end{array}$ & $\begin{array}{c}\text { SD } \\
\text { difference }\end{array}$ & $\begin{array}{l}\text { Probability } \\
\text { reliability }\end{array}$ \\
\hline Gator Belle & 32.38 & 6.48 & 7.69 & 0.80 \\
\hline Hybelle & 33.39 & 7.49 & 7.28 & 0.85 \\
\hline Skipper & 28.56 & 2.66 & 6.02 & 0.67 \\
\hline KRG\#3 & 25.90 & ... & --- & --- \\
\hline
\end{tabular}

${ }^{2}$ Wald test indicates significant differences among reliabilities for yield at $P=0.023$.

due to irrigation difficulties. The yields in 1986 in Attapulgus were not similar to those in all other locations; however, in 1987, the average yield in Attapulgus was significantly higher than the average across all other locations
(44.30 vs. $28.59 \mathrm{Mg} \cdot \mathrm{ha}^{-1}$ ). This difference may be more related to cool conditions in Attapulgus during the first 14 days after planting for each of the first two spring planting dates when the average night minimum was 13 


\section{Crop Production}

and $9 \mathrm{C}$, respectively. Additional research is needed to identify the specific physiological and environmental factors associated with these differences.

$R I$. The RI is based on two assumptions: the environments included in the analysis represent those encountered by growers within the region, and the standard cultivar normally is grown in the environments. The cultivars and locations evaluated in this project satisfy those requirements. Using commercial cultivars that reliably provide an improved yield over the standard cultivar could reduce the risk associated with cultivar selection and increase the stability of pepper production in this region. Our results indicate that yield increases over the standard KRG\#3 would be achieved more reliably by selecting hybrids 'Gator Belle' or 'Hybelle' rather than 'Skipper'. Although mean yields for 'Hybelle' and 'Gator Belle' were almost identical when averaged over all environments, 'Hybelle' would appear to be the cultivar of choice in Fletcher. As Plaisted and Peterson (1959) reported, the final measure of adaptation is how well the cultivar is accepted by farmers over several years. In addition, by identifying the characteristics of commercial pepper cultivars available to growers and including cultivars with reliable yield responses in the development and evaluation of production systems, research results appropriate to a broader range of environments can be realized.

\section{Literature Cited}

Bauer, L.L., J.E. Eperson, J.T. Garrett, and D.C. Sanders. 1989. The south Atlantic coast vegetable project: A multi-state team approach to research on alternative farming opportunities. HortScience 24:534.

Call, R.E. and J.W. Courter. 1989. Response of bell pepper to raised beds, black plastic mulch, spunbonded row cover and trickle irrigation. Proc. Natl. Agr. Plastics Congr. 21:140-146.

Cochran, H.L. 1936. Some factors influencing growth and fruit setting in pepper (Capsicum frutescens L. ). Cornell Agr. Expt. Sta. Memoir 190:1-39.

Crossa, J. 1990. Statistical analysis of multilocation trials. Adv. Agron. 44:55-85.

Deal, D.L. and J.C. Raulston. 1989. Plant night temperature tolerance zones: Describing and predicting summer night temperature patterns and the southern limits of plant adaptation. Agr. Forest Meteorol. 46:211-226.

Dorland, R.E. and F.W. Went. 1947. Plant growth under controlled conditions: VIII, Growth and fruiting of the chili pepper (Capsicum annuum). Amer. J. Bot. 34:393-401

Eberhart, S.A. and W.A. Russell. 1966. Stability parameters for comparing varieties. Crop Sci. 6:36-40.

Eskridge, K.M. and R.F. Mumm. 1992. Choosing plant cultivars based on the probability of outperforming a check. Theor. Appl. Genet. 84:494 500.

Findlay, K.W. and G.W. Wilkinson, 1963. The analysis of adaption in a plant breeding program. Austral. J. Agr. Res. 14:742-754.

Plaisted, R.L. and L.C. Peterson. 1959. A technique for evaluating the ability of selections to yield consistently in different locations or seasons. Amer. Potato J. 36:381-385.

Poysa, V.W., R. Garton, W.H. Courtney, J.G Metcalf, and J. Muehmer. 1986. Genotype-environment interactions in processing tomatoes in Ontario. J. Amer. Soc. Hort. Sci 111:293-297.

Quagliotti, L. 1979. Floral biology of Capsicum and Solanum melongena, p. 399-419. In: J.G. Hawkes (ed.). The biology and taxonomy of the Solanaceae. Academic, New York.

Sanders, D.C., T.R. Konsler, W.J. Lamont, and E.A. Estes. 1986. Pepper \& muskmelon economics when grown with plastic mulch and trickle irrigation. Proc. Natl. Agr. Plastics Congr. 19:302314.

U.S. Dept. of Agriculture. 1989. United States standards for grades of sweet peppers. Agricultural Marketing Service, U.S. Dept. of Agriculture, Washington, D.C.

Vavrina, C.S. 1988. Vegetables on increase in region. Southeast Farm Press, 20 Apr. p. 14. 